Session \# 2150-737

\title{
A 30 Year Survey of Rochester Institute of Technology Engineering Technology Graduates
}

\author{
Carol Richardson, John Stratton, and Maureen Valentine \\ Rochester Institute of Technology
}

\begin{abstract}
Rochester Institute of Technology (RIT) surveyed the alumni of its seven engineering technology (ET) programs in 1997 and again in 2002. RIT, along with three other universities with ET programs, published a paper on the results of the 1997 survey in the 1998 ASEE Conference Proceedings. This paper presents and analyzes the RIT 2002 ET alumni survey data and compares it to the RIT 1997 survey and ET alumni surveys of three other universities between 1990 and 1996. RIT surveyed over 3,000 ET alumni in 1997 and 5,632 alumni in 2002. The RIT alumni salary data obtained in the 1997 and 2002 surveys corresponds to salary data for engineers with job experience published by the Engineering Workforce Commission and has been a strong recruiting tool for freshman and transfer ET students. The two RIT alumni surveys document the achievements of the RIT ET graduates for the past thirty years and will be a strong assessment tool for the next RIT ABET Technology Commission 2000 (TC2K) accreditation visit. The ET salary surveys show that ET graduates are clearly rewarded as professionals on the engineering team.
\end{abstract}

\section{Introduction}

Rochester Institute of Technology (RIT) is a private university in upstate New York that enrolls more than 15,000 full and part-time undergraduate and graduate students preparing for technical and professional careers in more than 200 different academic programs. RIT attracts students from every state and more than 80 foreign countries and offers students work experience through the university's co-operative educational program. RIT, a pioneer in career-oriented education and a leader in cooperative education since 1912, has one of the oldest and largest co-op programs in the world, with more than 1,300 employers and 2,500 students participating. RIT's eight colleges include Applied Science and Technology, Business, Computing and Information Sciences, Engineering, Imaging Arts and Sciences, Liberal Arts, Science, and the primarily federally funded National Technical Institute for the Deaf. RIT's modern 1,300-acre campus is located in Rochester, the third-largest city in New York State.

\section{RIT ET History}

RIT baccalaureate programs in Electrical Engineering Technology (EET) and Mechanical Engineering Technology (MET) began in 1970 for transfer students from two-year engineering technology programs. Freshman and sophomore engineering technology courses were added in

"Proceedings of the 2004 American Society for Engineering Education Annual Conference \& Exposition Copyright c 2004, American Society for Engineering Education" 
1988, which allowed RIT to accept freshman students into the ET programs. Accreditation for the EET and MET programs was initially granted in 1975 by what has become the Technology Accreditation Commission of the Accreditation Board for Engineering and Technology in 1975. A Civil Engineering Technology (CET) program was accredited in 1975, Manufacturing Engineering Technology (MfET) in 1980, Computer Engineering Technology (CpET) in 1985, Telecommunications Engineering Technology (TET) in 1991, and Electrical/Mechanical Engineering Technology (EMET) in 1992. All of the seven current RIT ET baccalaureate programs are five-year programs that require 50 weeks of co-operative educational experience. This experience begins in the third year of each program and is generally accomplished in one 10 week (single block) and two 20 week (double block) experiences over a three year period. Students began graduating from the ET programs in 1973 with a Bachelor of Technology (BT) degree. The BT degree was changed to a Bachelor of Science degree in all ET programs by 1990.

\section{Benchmarks for ET Alumni Surveys}

Benchmarks for graduate salaries, job titles, graduate education, and professional certifications have been established in ET alumni surveys during the last decade at RIT, the University of Dayton, Old Dominion, Northeastern University, and the University of Pittsburgh at Johnstown (UPJ). RIT did two surveys, one in 1997 and one in 2002.

Two universities, the University of Dayton in 1990 and Old Dominion in1993, surveyed their alumni and established benchmarks for graduate satisfaction and professional certifications. The 1997 RIT alumni survey form was similar to the 1990 Dayton survey which established benchmarks for graduate education and professional certifications. The results of the Dayton survey were published by Robert Mott in the Journal of Engineering Technology in 1992. ${ }^{1}$ A survey at Old Dominion University was done in 1993 by W.D. Stanley and A.K. Verman and published in the 1996 ASEE Conference Proceedings. ${ }^{2}$

Northeastern University did a survey of all of their alumni with bachelor and associate degrees graduating between 1990 and 1996 in their MET, EET, and CpET programs and reported the results in the 1998 ASEE Proceedings in two different papers. Job titles of the MET alumni were reported in the 1998 ASEE Proceedings by Cole and Finn ${ }^{3}$ for the MET alumni and by Cole and Tapper for the EET alumni.

Professor James Hales of the Engineering Technology Division (ETD) of the UPJ reported on the results of 1990 and 1996 surveys of salary data and job titles in the 1998 ASEE Proceedings. ${ }^{5}$ The ETD of UPJ began collecting salary data in 1982. A comparison was made between the UPJ graduate salary data and that collected by the Engineering Workforce Commission (EWC) in 1996 for BS engineering graduates of all types of engineering programs. ${ }^{6}$ This data was compared to the average starting salaries of UPJ ET graduates.

The graduates of all RIT ET programs in the RIT alumni database were surveyed in 1997 and 2002. In 1997 RIT mailed over 3,000 surveys, and 550 alumni responded to this survey. The results of the 1997 RIT survey were published in the 1998 ASEE Proceedings. ${ }^{7}$ In 2002 RIT mailed 5,632 surveys and received 743 responses. Both of the RIT surveys collected salary

\footnotetext{
"Proceedings of the 2004 American Society for Engineering Education Annual Conference \& Exposition Copyright c 2004, American Society for Engineering Education"
} 
information, job titles and descriptions, graduate education, licenses or certifications, and professional society memberships. The 2002 RIT survey asked additional questions on technical skills and knowledge preparation, communication skills, and ethics education in the RIT ET programs for TC2K assessment. A copy of the 2002 RIT survey is provided in the appendix to this paper.

Salary Studies

Figure 1. Comparison of RIT ET Graduates to 2002 EWC National Engineering Salaries

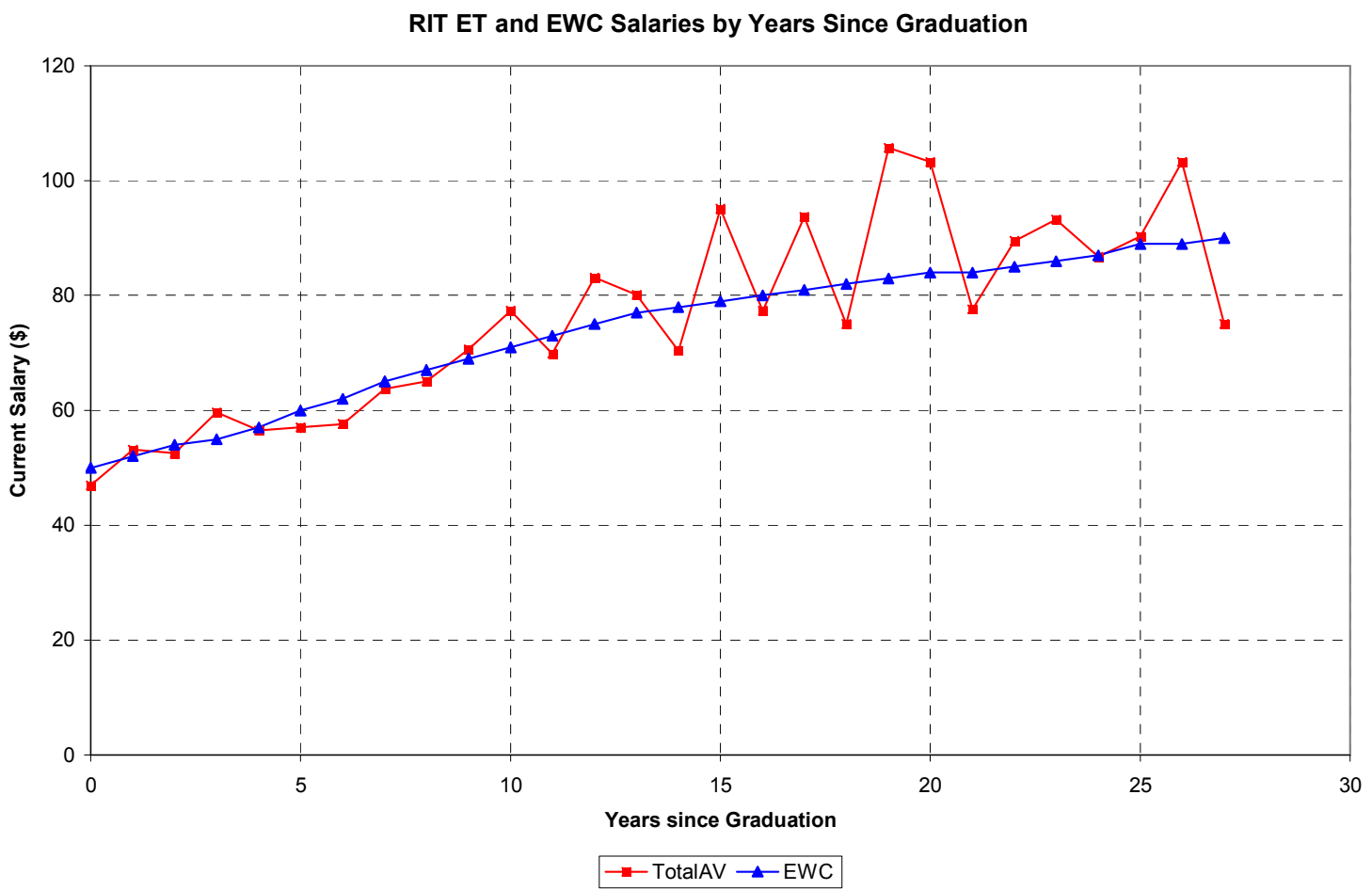

Figure 1 shows a comparison of RIT ET Graduates and 2002 salaries reported in the annual salary survey of the Engineering Workforce Commission (EWC) ${ }^{8}$. The 2002 RIT survey showed results similar to the 1997 RIT survey. Salaries of all ET RIT graduates tracked very well with those of the Engineering Workforce Commission summary of all engineering graduates. This shows that RIT ET graduates are monetarily rewarded as professionals on the engineering team.

The RIT 2002 salary survey results did show some differences among the ET disciplines, with Civil Engineering Technology graduates starting a bit lower and winding up a bit higher than the other ET disciplines after a few years. We have not shown this data, as we do not believe that the number of graduates in each discipline is large enough to be statistically significant.

The University of Pittsburgh at Johnstown (UPJ) salary surveys also compared the UPJ graduate salaries from 1982 to 1996 to the salary data from the EWC. The UPJ ET graduates of CET, EET, and MET programs received salaries that were lower than the EWC national average, but

"Proceedings of the 2004 American Society for Engineering Education Annual Conference \& Exposition Copyright c 2004, American Society for Engineering Education" 
the slope of the curves were similar. Another UPJ survey in 1996 showed that the average salaries of UPJ graduates with job experience had approached or exceeded the national averages. The first class of UPJ students graduated in 1975, and the first class of RIT students in CET, EET, and MET was in 1973. The first RIT salary survey was in 1997, which was much later than the first UPJ salary surveys. RIT ET graduates are required to obtain fifty weeks of cooperative work experience before they are certified in their five-year program, which increases their average starting salaries. The salary surveys at RIT and UPJ after 1996 show that ET graduate salary compensation is equal to the national average for all engineers.

\section{Job Titles}

Table 1 shows the difference in job titles between the two RIT surveys. Because the RIT 2002 alumni survey had a wider range of responses than the 1997 survey, the percentages of alumni with similar job titles as shown in Table 1 appears to decrease. The technician job title was reported by $4 \%$ of the respondents of the 1997 survey while only $1 \%$ of the respondents to the 2002 survey reported this as a job title.

Table 1. RIT ET Alumni Job Titles

\begin{tabular}{|l|c|c|}
\hline $\begin{array}{l}\text { RIT Alumni } \\
\text { Job Titles }\end{array}$ & 2002 Responses & 1997 Responses \\
\hline Engineer & $41 \%$ & $50 \%$ \\
\hline $\begin{array}{l}\text { General } \\
\text { Management }\end{array}$ & $20 \%$ & $10 \%$ \\
\hline $\begin{array}{l}\text { Technical } \\
\text { Services }\end{array}$ & $12 \%$ & Not a category \\
\hline $\begin{array}{l}\text { Engineering } \\
\text { Management }\end{array}$ & $10 \%$ & $17 \%$ \\
\hline $\begin{array}{l}\text { Senior } \\
\text { Management }\end{array}$ & $5 \%$ & $7 \%$ \\
\hline $\begin{array}{l}\text { Sales \& } \\
\text { Marketing }\end{array}$ & $4 \%$ & Not a category \\
\hline Other & $1 \%$ & $11 \%$ \\
\hline Technician & $6 \%$ & $4 \%$ \\
\hline
\end{tabular}

The survey in Appendix A asked the RIT ET alumni to list their current job title. Job titles were provided by 456 respondents on the 2002 RIT survey. The most common response was engineer. Senior management titles included owner, president, CEO, vice president, and general manager. General management job titles included director, manager, and supervisor. All Engineering Management job titles had the word engineering in the title and included engineering supervisor, engineering manager, and director of engineering. Job titles in Technical Services were analyst, designer, consultant, estimator, planner, inspector, programmer, scheduler, system administrator, technician, contractor, and production supervisor. Technical Services was not a category for the 1997 survey, and job titles in this category in 2002 included quality analyst, designer, specialist, estimator, technician, consultant, associate, inspector, planner, scheduler, senior research scientist, foreman, production supervisor, contractor, electrician, and information technology

"Proceedings of the 2004 American Society for Engineering Education Annual Conference \& Exposition Copyright c 2004, American Society for Engineering Education” 
titles such as programmer, system administrator, web developer, and software developer. The Other category in Table 1 was split evenly between ET-related and non-technical job titles, and some jobs were in education and the military. ET-related job titles in education were professor and technology teacher. Examples of non-technical military job titles were lieutenant commander and fighter pilot. No RIT ET alumni reported a job title of technologist in the 1997 or 2002 surveys.

The 1996 UPJ survey reported the results of job titles of EET, MET, and CET alumni. Ninetyseven percent of the UPJ graduates held professional titles in this survey which do not directly correspond to the titles in Table 1. Job titles of UPJ graduates with ten to twenty years of work experience were chief engineer, senior engineer, director of engineering, design engineer, president/owner, project engineer, associate professor, department manager, and team leader.

The MET Northeastern University survey job titles were engineer, manager, technician, designer, student, and other. Northeastern University reported that 43 of $55(75 \%)$ respondents with a MET bachelor degree were functioning as either an engineer or manager and 6 of 55 $(10 \%)$ as technicians or designers while $50 \%$ of the associate degree respondents were working as technicians or designers. Northeastern University reported that 45 of $62(70 \%)$ of the EET BS graduates were functioning as either an engineer or manager and 4 of $62(6 \%)$ as technicians.

The University of Dayton survey (1992-1996) reported that over 99\% of the ET graduates were working in technical positions pertinent to their fields, and less than $1 \%$ reported that they were working in a non-technical field.

Job Duties

Table 2. RIT and University of Dayton Job Duties Responses

\begin{tabular}{|l|l|l|l|}
\hline RIT Alumni Job Duties & 2002 RIT & 1997 RIT & 1996 U of D \\
\hline Engineering Management & $27 \%$ & $20 \%$ & \\
\hline Engineering Design & $21 \%$ & $16 \%$ & $8 \%$ (Design Eng.) \\
\hline General Management & $18 \%$ & $7 \%$ & $20 \%$ \\
\hline Consulting & $14 \%$ & Not a category & \\
\hline Technical Services & $14 \%$ & $7 \%$ & \\
\hline Construction & $14 \%$ & $8 \%$ & \\
\hline Product Development & $13 \%$ & $6 \%$ & $6 \%$ \\
\hline Sales and Marketing & $13 \%$ & $4 \%$ & $5 \%$ \\
\hline Field/Applications Eng. & $13 \%$ & $8 \%$ & $3 \%$ \\
\hline Manufacturing Eng. & $10 \%$ & $9 \%$ & $20 \%$ (+ Mgt.) \\
\hline $\begin{array}{l}\text { Product } \\
\text { Evaluation/Testing }\end{array}$ & $10 \%$ & $5 \%$ & $2 \%$ \\
\hline $\begin{array}{l}\text { Hardware/Software } \\
\text { Development }\end{array}$ & $9 \%$ & $9 \%$ & $4 \%$ \\
\hline Systems Design & $8 \%$ & $7 \%$ & $5 \%$ (Process Design) \\
\hline Quality Assurance & $8 \%$ & $6 \%$ & $5 \%$ \\
\hline Product Design & $7 \%$ & $6 \%$ & \\
\hline
\end{tabular}

"Proceedings of the 2004 American Society for Engineering Education Annual Conference \& Exposition Copyright c 2004, American Society for Engineering Education" 
The 2002 RIT survey provided 30 different job duty choices for the alumni to identify. The 678 alumni who completed the survey identified 1,764 self-described job duties. Design and Development job duties were described as engineering design, consulting, hardware and software design, product development, process design, system design, research and development, and product planning. Management job duties included engineering management, general management, plant engineering management, and manufacturing operations management. Quality Assurance job duties were product evaluation and testing, methods and standards engineering, and product planning and control. Graduates were encouraged to check every box that applied to their job, so the totals will be more than $100 \%$.

The University of Dayton survey (1992-1996) had a 44\% response rate from the graduates of four ET programs. A significant increase was seen in the percent of ET graduates going into general management functions within five years of graduation. In 1991 the University of Dayton ET alumni in general management was $6 \%$, design-related functions $31 \%$, manufacturing-related functions $28 \%$, and sales/services functions $25 \%$.

\section{Graduate Education}

Table 3 RIT Graduate Education by Program

\begin{tabular}{|c|c|c|c|c|c|c|c|}
\hline \multirow[t]{2}{*}{ ET Program } & $\begin{array}{l}\text { MBA } \\
2002\end{array}$ & $\begin{array}{l}\text { MS Any } \\
\text { Field } 2002\end{array}$ & $\begin{array}{l}\mathrm{MS}+ \\
\mathrm{MBA}\end{array}$ & \multicolumn{2}{|c|}{$\begin{array}{l}\text { Alumni with } \\
\text { some grad. work }\end{array}$} & \multicolumn{2}{|c|}{$\begin{array}{l}\text { Alumni with } \\
\text { graduate degrees }\end{array}$} \\
\hline & & & & 2002 & 1997 & 2002 & 1997 \\
\hline Civil & 12 & 16 & 28 & $16 \%$ & & $14 \%$ & \\
\hline Computer & 1 & 7 & 8 & $24 \%$ & & $22 \%$ & \\
\hline Electrical & 26 & 32 & 58 & $33 \%$ & & $30 \%$ & \\
\hline Manufacturing & 4 & 12 & 16 & $32 \%$ & & $32 \%$ & \\
\hline Mechanical & 10 & 14 & 24 & $20 \%$ & & $15 \%$ & \\
\hline Telecom & 2 & 2 & 4 & $25 \%$ & & $17 \%$ & \\
\hline Unidentified & 5 & 3 & 8 & $15 \%$ & & $15 \%$ & \\
\hline All ET & 60 & 86 & 146 & $23 \%$ & $36 \%$ & $21 \%$ & $24 \%$ \\
\hline
\end{tabular}

Table 3 summarizes the amount of graduate education reported by the respondents in each RIT ET program in the 2002 survey and Table 4 identifies the year that the alumni graduated from RIT. Two PhD degrees were reported in the 1997 survey; none were reported in the 2002 survey. The Master of Business Administration (MBA) continued to be a popular graduate degree in the RIT 2002 survey. Most of the Master of Science (MS) degrees in both the 1997 and 2002 RIT surveys were in engineering, engineering management, or a specialized technology. There were a few MS degrees in both the 1997 and 2002 surveys in fields not directly related to ET or management, such as education.

The Northeastern University surveys indicated that 13 (22\%) of 59 MET respondents and 19 of $65(30 \%)$ of the EET BS graduates were pursuing advanced degrees. The University of Dayton survey (1992-1996), with 546 ET graduate respondents, had about a third of the respondents

"Proceedings of the 2004 American Society for Engineering Education Annual Conference \& Exposition Copyright c 2004, American Society for Engineering Education" 
reporting that they were pursuing or had completed a Master's degree. The most common degrees were an MBA, Management Science, or Industrial Management degree.

Table 4. RIT Graduate Education by Graduation Year for all ET Programs

\begin{tabular}{|c|c|c|c|c|c|c|}
\hline $\begin{array}{l}\text { Graduation } \\
\text { Year }\end{array}$ & $\begin{array}{l}\text { MBA } \\
2002\end{array}$ & $\begin{array}{l}\text { MBA } \\
1997\end{array}$ & $\begin{array}{l}\text { MS Any } \\
\text { Field } 2002\end{array}$ & $\begin{array}{l}\text { MS Any } \\
\text { Field } 1997\end{array}$ & $\begin{array}{l}\mathrm{MS}+\mathrm{MBA} \\
2002\end{array}$ & $\begin{array}{l}\text { MS +MBA } \\
1997\end{array}$ \\
\hline 74-79 & 5 & 15 & 14 & 12 & 19 & 27 \\
\hline $80-84$ & 18 & 17 & 14 & 13 & 32 & 30 \\
\hline $85-89$ & 11 & 11 & 12 & 17 & 23 & 28 \\
\hline $90-94$ & 9 & & 23 & & 32 & \\
\hline $95-99$ & 8 & & 18 & & 26 & \\
\hline $90-96$ & & 3 & & 8 & & 11 \\
\hline Unidentified & 7 & & 4 & & & 11 \\
\hline $\begin{array}{l}\text { \% Total } \\
2002 \\
\text { Respondents }\end{array}$ & $8 \%$ & & $12 \%$ & & $20 \%$ & \\
\hline
\end{tabular}

Licenses or Certifications

Certificates and professional licensure represent a measure of accomplishment and life-long learning. Therefore, we asked the RIT alumni to identify the various licenses and certifications that they have acquired since graduation from RIT. The Fundamentals of Engineering (FE) and Professional Engineer (PE) examinations represent a multi-disciplinary certification, but our results, presented in Table 5, clearly show that these certifications are the most important to CET graduates. Other certifications for CET alumni included certified safety professional, NICET, wastewater and plant operator, and general building contractor. The RIT TET program began in 1989 and had the first graduates in 1992. The sample size of TET alumni was not significant in 1997, so percentages were not calculated for the TET program. Certifications reported in 2002 by the TET, EET, and CpET alumni were predominantly Cisco and Microsoft certifications. The MfET and MET RIT alumni certifications were certified manufacturing engineer (CmfgE), plant engineer, NRC, PMP, and CQE, although none of these certifications were reported in large numbers.

Table 5. RIT Professional Engineering Licenses and other Certifications

\begin{tabular}{|l|l|l|l|l|l|l|}
\hline ET Program & $\begin{array}{l}2002 \\
\text { Passed } \\
\text { the FE }\end{array}$ & $\begin{array}{l}1997 \\
\text { Passed } \\
\text { the FE }\end{array}$ & $\begin{array}{l}2002 \\
\text { Passed } \\
\text { the PE }\end{array}$ & $\begin{array}{l}1997 \\
\text { passed } \\
\text { the PE }\end{array}$ & $\begin{array}{l}2002 \\
\text { Received } \\
\text { other Cert. }\end{array}$ & $\begin{array}{l}1997 \\
\text { Received } \\
\text { other Cert. }\end{array}$ \\
\hline Civil & $27 \%$ & $30 \%$ & $34 \%$ & $24 \%$ & $13 \%$ & $24 \%$ \\
\hline Computer & $0 \%$ & $0 \%$ & $0 \%$ & $0 \%$ & $16 \%$ & $39 \%$ \\
\hline Electrical & $4 \%$ & $0 \%$ & $4 \%$ & $2 \%$ & $10 \%$ & $35 \%$ \\
\hline Manufacturing & $8 \%$ & $0 \%$ & $6 \%$ & $0 \%$ & $16 \%$ & $56 \%$ \\
\hline Mechanical & $0 \%$ & $0 \%$ & $0 \%$ & $0 \%$ & $10 \%$ & $49 \%$ \\
\hline Telecom & $0 \%$ & $\mathrm{NS}$ & $0 \%$ & $\mathrm{NS}$ & $46 \%$ & $\mathrm{NS}$ \\
\hline
\end{tabular}

"Proceedings of the 2004 American Society for Engineering Education Annual Conference \& Exposition Copyright c 2004, American Society for Engineering Education" 
The University of Pittsburgh at Johnstown (UPJ) 1996 survey reported the percentage of UPJ graduates in CET, EET, and MET programs completing the Fundamentals of Engineering (FE) Exam or being a registered Professional Engineer $(\mathrm{PE})$ and compared this percentage to students in Engineering Accreditation Commission (EAC)/ABET programs taking the FE exam for the first time. EAC/ABET program students had pass rates of $83 \%$ and $86 \%$, respectively for the October 1996 and April 1997 FE exams. First-time students from non-EAC/ABET programs had pass rates of $61 \%$ and $58 \%$, respectively. ${ }^{9}$ There were 219 UPJ graduates that responded to the 1996 survey, and 187 (85\%) identified themselves as successfully completing the FE exam or being a registered $\mathrm{PE}$.

The Northeastern University survey of their alumni with bachelor and associate degrees graduating between 1990 and 1996 in their MET, EET, and CpET programs reported that 10 (17\%) had passed the FE examination. Old Dominion reported that $28 \%$ of the alumni who had graduated in the past 19 years had passed the FE exam in their 1993 survey.

The surveys show that universities with CET programs have higher pass rates for the FE examination. Northeastern and RIT have similar pass rates for their EET and MET graduates.

\section{Professional Society Memberships}

Table 6. RIT Professional Society Memberships by Program

\begin{tabular}{|l|c|c|l|l|}
\hline Program & \#Alumni 2002 & \#Society 2002 & $\% 2002$ & $\% 1997$ \\
\hline Civil & 200 & 114 & $57 \%$ & $46 \%$ \\
\hline Computer & 37 & 9 & $24 \%$ & $36 \%$ \\
\hline Electrical & 192 & 60 & $31 \%$ & $36 \%$ \\
\hline Elect./Mech. & 3 & 3 & $100 \%$ & $56 \%$ \\
\hline Manufacturing & 50 & 26 & $52 \%$ & $56 \%$ \\
\hline Mechanical & 157 & 65 & $41 \%$ & $48 \%$ \\
\hline Telecom & 24 & 7 & $29 \%$ & $0 \%$ \\
\hline ET Overall & & & $43 \%$ & $44 \%$ \\
\hline
\end{tabular}

Table 6 shows the number of alumni in each RIT BS ET program that belong to a professional society as reported in the 2002 survey and provides percentages for both the 2002 and 1997 surveys. The results show that there are variations among ET disciplines and that the overall professional society activity hasn't changed in the past five years. The Northeastern University survey reported that $17 \%$ of the MET alumni and $23 \%$ of the EET alumni had professional society memberships.

\section{Graduate Satisfaction}

RIT ET alumni were asked the questions shown below in Table 7 in the 2002 survey and asked to rank them on a scale from 1(unsatisfied), 2 (somewhat satisfied), 3(satisfied) 4 (quite satisfied) to 5(very satisfied). Two of these questions were asked on the RIT 1997 survey.

"Proceedings of the 2004 American Society for Engineering Education Annual Conference \& Exposition Copyright c 2004, American Society for Engineering Education" 
Both of the RIT surveys also requested information on the favorite/least favorite course and the program emphasis that was most important to the graduate. Engineering Economics, Ethics, and Technical Writing and Presentation were listed as the most important courses in the 2002 survey which should be included in the curriculum. No courses were really the least.

RIT graduates felt that group work, practices relating to business and management, and preparation for the FE/PE exams were important. Other topics were related to individual disciplines. New emphasis in ISO certifications and ethics was suggested.

Table 7. RIT Graduate Satisfaction

\begin{tabular}{|c|c|c|}
\hline $\begin{array}{l}\text { Question How well did the ET/RIT program that you } \\
\text { graduated from ... }\end{array}$ & 2002 & 1997 \\
\hline $\begin{array}{l}\text { 1. ...prepare you with the technical skills and knowledge } \\
\text { necessary to be successful in your chosen field? }\end{array}$ & 4.14 & \\
\hline $\begin{array}{l}\text { 2. ...prepare you with the communication skills necessary to be } \\
\text { successful in your chosen field? }\end{array}$ & 3.86 & \\
\hline $\begin{array}{l}\text { 3. ...prepare you to continue your formal education and receive } \\
\text { subsequent degrees, certifications, or }\end{array}$ & 3.79 & \\
\hline $\begin{array}{l}\text { 4. ...prepare you to continue to gain skills and knowledge in informal } \\
\text { ways such as self-teaching, company training and learning by doing? }\end{array}$ & 4.15 & \\
\hline 5. ...prepare you to succeed in a business environment? & 3.76 & \\
\hline $\begin{array}{l}\text { 6. ... encourage you to maintain a high standard of integrity } \\
\text { and ethical conduct? }\end{array}$ & 4.06 & \\
\hline 7. ...prepare you for overall success in your chosen field? & 4.09 & 3.96 \\
\hline $\begin{array}{l}\text { 8. How satisfied were you with your education from } \\
\text { RIT immediately after graduation? }\end{array}$ & 3.97 & \\
\hline 9. How satisfied are you with your education from RIT today? & 4.02 & 4.01 \\
\hline
\end{tabular}

The Northeastern University survey of all of its MET graduates reported that the most important skill cited by the alumni were problem solving, teamwork, professional ethics, accomplishing tasks within the organization, and oral communications, and the least important skills were traditional computer programming, calculus, and differential equations. Northeastern University also reported that EET graduates reported important skills as problem solving, accomplishing tasks within the organization, teamwork, oral communications, professional ethics, writing skills, and use of personal computer tools, and the least important skills as differential equations, calculus, and basic MET skills such as thermo/fluids and materials.

\section{Conclusions}

The salaries of RIT and UPJ ET graduates continue to track well with salaries reported by the Engineering Workforce Commission for engineers who have been working for one to thirty years. The starting salaries for the RIT ET graduates may be enhanced by their required cooperative work experiences. The job titles and job descriptions continue to show that ET graduates from programs at three different universities are working in the more applied end of

"Proceedings of the 2004 American Society for Engineering Education Annual Conference \& Exposition Copyright c 2004, American Society for Engineering Education" 
the engineering job spectrum and that some of these titles and descriptions have changed in the past six years. ET graduates from three different universities are continuing to obtain graduate degrees in significant numbers although the percentage of RIT graduate degrees has decreased slightly from the 1997 survey. A professional engineering license is still sought by a significant number of the ET alumni of the civil engineering technology programs, and the percentage of alumni at RIT with this license has increased from the 1997 survey. The two RIT surveys showed that over 40\% of the RIT ET alumni are members of a professional society and the 1996 Northeastern survey reported approximately 20\%. New questions on the RIT 2002 survey indicated that RIT ET alumni are well prepared with technical skills and knowledge and can continue gaining skills and knowledge in informal ways. RIT ET alumni reported that they have been encouraged by their RIT education to maintain a high standard of integrity and ethical conduct.

RIT would like to thank the ET programs that have reported their alumni salary surveys in ASEE Proceedings and would like to encourage other schools to survey their ET graduates and report the results of these surveys so national benchmarks can continue to be established for accreditation reviews of student outcomes. These surveys could also be used to enhance all ET recruiting programs.

\section{CAROL RICHARDSON}

Professor Richardson has been the Department Chair at RIT for the Department of Electrical, Computer, and Telecommunications Engineering Technology since 1995 and has been teaching at RIT for 25 years. She received her BSEE degree from the University of Wyoming, her MSEE degree from Union College, and worked 10 years in industry prior to joining RIT.

\section{JOHN STRATTON}

Professor Stratton has chaired two different ET departments at RIT and served as the Associate Dean of the College of Applied Science and Technology for the past 24 years. This year he is on sabbatical and will be returning to his first love of teaching full time. He has a BSEE degree from RIT and an MSEE from Rensselaer Polytechnic Institute. He worked three years in industry before entering teaching in 1969 and continues to consult on a part time basis.

\section{MAUREEN VALENTINE}

Professor Valentine, P.E., has been a faculty member at RIT for over ten years and has held the position of Department Chair for the Department of Civil Engineering Technology, Environmental Management, and Safety since 2000. She received her BSCE degree from Tufts University, her ME in Geotechnical Engineering from Virginia Tech, and has practiced as a consulting engineer for the past 14 years. 


\section{Appendix A \\ Alumni Survey 2002 \\ Rochester Institute of Technology Engineering Technology Department \\ College of Applied Science and Technology \\ All information is confidential - no individual information will be reported}

\section{Please complete the following:}

1. Identification (optional)

Name:

Telephone:

Email:

Address:

2 a. Degree(s) received from RIT

$\square$ AAS $\square$ BS

2 b. Program

$\square$ Electrical $\square$ Computer $\square$ Telecommunications $\square$ Electrical/Mechanical

$\square$ Civil $\square$ Mechanical $\square$ Manufacturing

2 c. Year graduated

3. Other degrees or certificates received or in progress

Institution

Type* Program

Year Completed/In Progress

* Please enter "T" for company training, "A" for associates, "B" for bachelors, "C" for courses, "M" for masters, "D" for doctorate or "O" for other

4. Licenses or Certifications:

Please indicate any special licenses or certifications you may have received

[ ]FE [ ]PE [ ]CMfgE [ ]LSIT [ ]LS [ ] Cisco [ ]Microsoft

[ ] Other (Specify)

"Proceedings of the 2004 American Society for Engineering Education Annual Conference \& Exposition

Copyright c 2004, American Society for Engineering Education" 
5. Current employment

Employer Job Title or Description

Annual compensation (optional, but very valuable to our graduates \& alumni, individual information is confidential):

\section{Description of Duties}

Check the item(s) which describes your present position
[ ] General Management
[ ] Engineering Management
[ ] Manufacturing/Operations Management
[ ] Plant Engineering Management
[ ] Sales and Marketing
[ ] Purchasing
[ ] Technical Services
[ ] Field/Application Engineering
[ ] Product Planning
[ ] Environmental Engineering
[ ] Construction
[ ] Other Technical (specify)
[ ] Consulting
[ ] Systems Design
[ ] Product Development
[ ] Product Evaluation or Testing
[ ] Hardware/Software Development
[ ] Controls Engineering
[ ] Manufacturing Engineering
[ ] Process Design
[ ] Plant Engineering
[ ] Methods/Standards Engineering
[ ] Quality Assurance
[ ] Production Planning and Control
[ ] Research and Development
[ ] Education
[ ] Product Design
[ ] Engineering Design
[ ] Other Non-Technical
[ ] Heating, Ventilating and $A / C$

7. List Professional or Trade Organization Memberships

II. Please answer the following questions by marking the appropriate box.

How well did the ET/RIT program that you graduated from ...

8. ...prepare you with the technical skills and knowledge necessary to be successful in your chosen field?

\begin{tabular}{|l|c|c|c|c|}
\hline Not at All & $\begin{array}{c}\text { Insuf- } \\
\text { ficiently }\end{array}$ & $\begin{array}{c}\text { Well } \\
\text { Enough }\end{array}$ & $\begin{array}{c}\text { Fairly } \\
\text { Well }\end{array}$ & Very Well \\
\hline & & & & \\
& & & & \\
\hline
\end{tabular}

"Proceedings of the 2004 American Society for Engineering Education Annual Conference \& Exposition Copyright c 2004, American Society for Engineering Education" 
9. ...prepare you with the communication skills necessary to be successful in your chosen field?

10. ...prepare you to continue your formal education and receive subsequent degrees, certifications, or

11....prepare you to continue to gain skills and knowledge in informal ways such as self-teaching, company training and learning by doing?

12. ...prepare you to succeed in a business environment?

13. ...encourage you to maintain a high standard of integrity and ethical conduct?

14. ...prepare you for overall success in your chosen field?

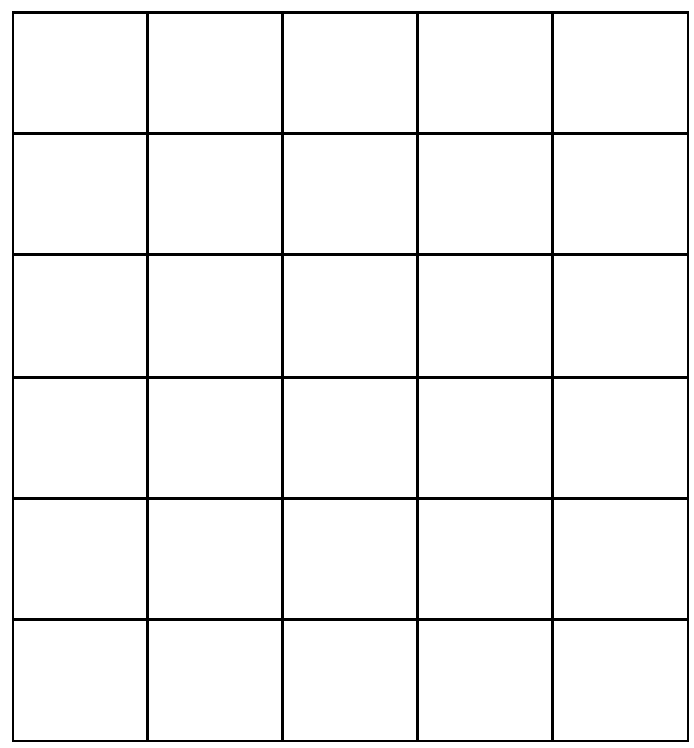

\begin{tabular}{|c|c|c|c|c|}
\hline $\begin{array}{c}\text { Un- } \\
\text { satisfied }\end{array}$ & $\begin{array}{c}\text { Some- } \\
\text { what } \\
\text { Satisfied }\end{array}$ & Satisfied & $\begin{array}{c}\text { Quite } \\
\text { Satisfied }\end{array}$ & $\begin{array}{c}\text { Very } \\
\text { Satisfied }\end{array}$ \\
\hline & & & & \\
\hline & & & & \\
\hline
\end{tabular}

III. Please answer the following questions:

17. What were the three most useful courses you took while earning your degree from RIT? Please list in order of importance.

1. (most important)

2.

3.

18. What were the three least useful courses you took while earning your degree from RIT? Please list in order of importance

1. (least important)

2.

3.

"Proceedings of the 2004 American Society for Engineering Education Annual Conference \& Exposition Copyright c 2004, American Society for Engineering Education" 
19. I believe that my program should have placed more emphasis on

20. I believe that my program should have placed less emphasis on

21. I believe that my program should add new emphasis on

22. Would you be interested in a graduate program offered by RIT?

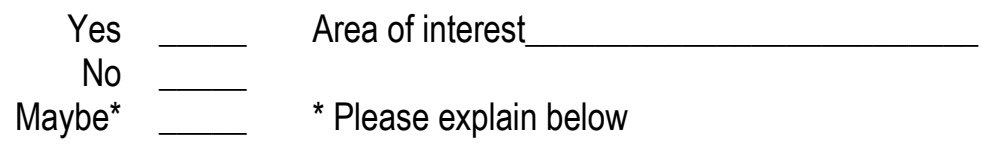

${ }^{1}$ Mott, Robert L. "Twenty-five Years of Success with the Baccalaureate Degree in Engineering Technology" Journal of Engineering Technology, Vol. 9 Washington DC: The American Society for Engineering Education, 1992

${ }^{2}$ Stanley, William D. and Verma, Alok K. "Long Term Performance of Old Dominion University Engineering Technology Graduates" 1996 Annual Conference Proceedings, Washington, DC, The American Society for Engineering Education

${ }^{3}$ Cole, William E. and Finn, Charles W. "MET Graduate Survey Results" 1998 Annual Conference Proceedings, Washington, DC, The American Society for Engineering Education

${ }^{4}$ Cole, William E. and Finn, Charles W. "MET Graduate Survey Results" 1998 Annual Conference Proceedings, Washington, DC, The American Society for Engineering Education

${ }^{5}$ Hales, James L. and Hunter, Beverly J. “ A Twenty-Year History: Prospective From the Past”, 1998 Annual Conference Proceedings, Washington, DC, The American Society for Engineering Education

${ }^{6}$ Engineering Workforce Commission of the American Association of Engineering Societies, "Compensation, 1996: Finally Real Improvements in Pay" Engineers, vol. 2, No.3, July, 1996, p.3

${ }^{7}$ Stratton, John "How Are the Engineering Technology Graduates Doing? A Rochester Institute of Technology 25 Year Survey "1998 Annual Conference Proceedings, Washington, DC, The American Society for Engineering Education

${ }^{8}$ Engineering Workforce Commission .......

${ }^{9}$ Siegel, D. "Do EAC-ABET Grads Deserve FE Exam Exemption? Engineering Times, Vol.19, No. 7 July 1997, p.10

"Proceedings of the 2004 American Society for Engineering Education Annual Conference \& Exposition

Copyright c 2004, American Society for Engineering Education" 